\title{
The Kaleidoscopic World Confronts a Pandemic
}

\author{
Edith Brown Weiss
}

We must, indeed, all hang together or, most assuredly, we shall all hang separately. ${ }^{1}$

More than 216.3 million people worldwide are infected with the coronavirus as of late August 2021 and more than 4.5 million have died. ${ }^{2}$ And the numbers keep climbing. These data likely understate the extent of the crisis since testing is not widely available in many countries and deaths may go unreported.

The COVID-19 crisis affects people and countries unequally. It has the most severe effects on people with low incomes, indigenous peoples, minorities, people suffering discrimination, and people vulnerable through age or underlying health conditions. It severely harms countries that lack an adequate health care system, which unfortunately includes many countries, especially in Africa. In this crisis, each country has largely dealt with the problem on its own.

The COVID-19 crisis illustrates the workings of a kaleidoscopic world, in which patterns rapidly change, many actors beyond States are critical, flexible instruments are imperative, and scientific knowledge is evolving. The kaleidoscopic world stands in sharp contrast to the traditional view of an international system dominated by States in a rather static order, in which States enter binding agreements and are responsible for implementing them. The COVID-19 virus challenges this classical framework. It forces us to reconsider

1 Benjamin Franklin, on the occasion of the signing of the U.S. Declaration of Independence (1776): Walter Isaacson, 'Declaring Independence: How They Chose These Words' Time Magazine (7 July 2003) <http://content.time.com/time/magazine/article/o,9171,1005150 -3 ,oo.html $>$ accessed 27 April 27, 2021. The analysis for this essay was completed in November 2020.

2 WHO Coronavirus (Covid-19) Dashboard, https://covidı.who.int/ (visited 30 August 2021).

(C) EDITH BROWN WEISS, 2022 | DOI:10.1163/9789004472365_016

This is an open access chapter distributed under the terms of the CC BY-NC-NDAiQlicensen Weiss - 9789004472365 
international law in order to broaden its scope, enlarge the range of actors, encompass different kinds of legal instruments, and recognize the imperative of norms.

The coronavirus knows no geographical boundaries. It is readily transmissible and can easily hop a ride undetected to every corner of the Earth. Those people carrying and spreading the virus may be asymptomatic. International conferences, tourism venues such as ski resorts, and social, commercial, and religious places where people congregate en masse can become superspreader events, usually unknowingly. The international Biogen conference in Boston in late February 2020 , for example, is estimated to have unknowingly caused the infection of 20,000 people in the Boston area alone. ${ }^{3}$

At the beginning of the pandemic, little was known scientifically about the virus, especially about whether it could be transmitted by those showing no symptoms. Scientific knowledge about COVID-19 has rapidly changed. We are still learning much about the virus: its transmission, susceptibility of children, mutations of the virus, immunity and re-infection, long-term effects from having the virus, effective ways to control it, and many other features. As knowledge develops, public health measures to control and manage it change, often quickly.

Controlling the virus is a public goods problem, in which rapid responses by governments and other actors are essential and in which collective actions are needed at the local, regional, and global levels. At the same time, it presents a private goods problem: development of a vaccine by private companies, although often with public support. CoviD-19 presents us with the need for all actors, public and private, to collaborate and to respond quickly and flexibly.

The COVID-19 crisis is linked with other crises. The responses needed to confront COVID-19 dramatically affect daily life and lead to harsh economic effects. Thus, we are confronting two simultaneous crises: health and economic. While we treat these separately, they are intricately linked. Both are at the same time globalized and localized, even to the point of individual behaviour. They beg for global cooperation.

3 Jacob Lemieux and others, 'Phylogenetic analysis of SARS-CoV-2 in the Boston area highlights the role of recurrent importation and superspreading events' (medRxiv, 25 August 2020) <https://www.medrxiv.org/content/10.1101/2020.08.23.20178236vi.full.pdf> accessed 13 September 2020 . 
The health and economic crises co-exist with a third crisis: the climate crisis. The climate crisis is longer term, but the climate changes that are taking place already affect susceptibility to disease and efforts to control it. The climate crisis is advancing much faster than expected several decades ago and with greater severity. It will have significant implications for our capacity to address health and economic crises.

\section{Limits of International Law for the coviD-19 Pandemic}

The international legal system applicable to COVID-19 is centred on the World Health Organization (wHO). The wHO, with 194 member countries, has adopted binding international regulations and nonbinding legal instruments applicable to Covid-19. ${ }^{4}$ The wHO International Health Regulations (2005), the relevant instrument, contains 66 articles and nine annexes and specifies requirements for preparedness for controlling global disease transmission, including surveillance, notification and sharing of information, infection prevention and control, border controls, and measures to maintain essential health services. If the Director-General (DG) declares a Public Health Emergency of International Concern (PHEIC), the DG can issue standing and temporary recommendations to States. There is agreement among experts that it is again time to update these regulations.

The wHO system is by its structure focused on member States. It acts through regional bodies of member States. The wHo depends upon States implementing its regulations and recommendations and having the capacity and resources to do so. In many countries, these resources are lacking, either because the health systems are under-developed and underfunded, or because they are not designed to handle epidemics. Implementation of measures at the national level is spotty at best. The force of the wHo regulations and recommendations also depends upon States' willingness to accept the authority of the wHO and upon the WHo's capacity to avoid being captured by geopolitical or commercial considerations.

COVID-19 sharply raises the question of whether international law as classically conceived can effectively deal with a global pandemic in the current rather anarchic world. The answer seems to be "No." It is certainly relevant and important, but not sufficient. In practice, we are seeing a widely diverse set of regulations and recommendations by many different entities, from States

4 See Lawrence Gostin, Global Health Law (Harvard University Press 2014). 
operating alone at the national level, to subnational regulations, to very local measures, and to actions by actors other than States, including the private sector and industry, nongovernmental organizations, schools, and diverse networks.

The classical or legacy international legal system is based solely on States, which are sovereign, independent, territorially defined, and theoretically equal. It is horizontal in structure in that it governs relations between States. It focuses on a limited number of sources: binding international agreements, rules of customary international law, and general principles of law. It does not easily accommodate change. International law is also stove-piped in that separate areas of law have arisen for different subjects, as for example health, economic, security, environment, and human rights, sometimes without recognition of the common core elements. While the wHo has attempted to balance health concerns with trade and human rights concerns in its regulatory work, trade law generally has not reciprocated, except for the wто Doha Declaration on the TRIPS Agreement and Public Health, which permits compulsory licensing of pharmaceuticals for "national emergencies" and "circumstances of extreme urgency," as determined by the wTо Member. The challenging economic crisis today, which is linked with the health crisis, involves a separate body of international economic law.

In public international law, international and domestic law are fully distinct, although in practice domestic laws may sometimes extend beyond the country, and international law may need national implementing legislation to become binding within a given country. Similarly, the lines between public and private international law are sharply drawn, though they have blurred in recent years.

This classical framework of international law, centred on the wHO in the context of the pandemic, is certainly relevant, but it does not encompass the many actors and legal instruments that are relevant to controlling Covid-19. The private sector and civil society are critical to addressing the pandemic, but they participate only on the fringes. Measures at the subnational and local levels are not included. Many different kinds of instruments are relevant, such as guidelines and best practices, which do not rise to the status of binding commitments. States' incentives (whether inducements or sanctions) to implement and comply with the international legal commitments that do exist are weak.

Many States seem to be seizing on the basic principle of national sovereignty to strengthen national barriers and focus only on conditions within their own country in the pandemic. Closing national borders to travel (or closing subnational borders) to prevent importing the virus and quarantining those who 
enter respond to concerns about how easily the virus is transmitted. Most States seem to be acting on their own, with no consensus on criteria or without co-ordination. The European Union, in which States have generally not coordinated their actions, announced in October 2020 , however, a new colorcoded map indicating the travel risk for each of its 27 member countries, based on common criteria. It has further created an EU Digital COVID Certificate Regulation, which applies as of July 1, 2021.

Similarly, there is no consensus on the distribution of vaccines. A State that develops a vaccine can keep it for its own citizens as an exercise of national sovereignty. Other States, with wHO support, demand international access to a vaccine as an issue of equity. Moreover, national sovereignty can become a basis for controlling access to data and information needed to understand and respond to the pandemic. Accurate public information about the crisis is essential to enlisting public participation in addressing it. Controlling the virus is unnecessarily complicated when officials use the crisis to crack down on civil liberties or insist on libertarian ethics for personal or political gain.

\section{3}

Reconceptualizing Public International Law ${ }^{5}$

The CoviD-19 pandemic is taking place in the context of a fundamental transformation of the international system. The emerging order is complex and often chaotic. It consists of 193 States that are members of the United Nations and two with observer status, about 69,0oo international organizations (both governmental and nongovernmental), thousands of multinational corporations, multiple religious entities, many illicit actors and 7.8 billion people as of August 2021. Change is rapid as new issues and problems emerge, coalitions form instantly across national borders, and many different actors try to exercise authority. I have termed this landscape a kaleidoscopic world.

The kaleidoscopic world involves many actors beyond the wHO and States in the effort to control CoviD-19. These include subnational governments, local communities, the private sector, nongovernmental organizations, scientific and medical networks, informal networks, and individuals. All are engaged in public activities in trying to control the virus and its effects, or in some cases, to undercut existing control efforts, or to promote alternative responses to

5 The material that follows is based on work developed for my General Course on Public International Law at The Hague Academy of International Law, Edith Brown Weiss, 'Establishing Norms in a Kaleidoscopic World, General Course on Public International Law' (2019) 396 Recueil des Cours 1. 
measures recommended by public health experts for controlling transmission of the virus, as in the Great Barrington Declaration in October 2020. ${ }^{6}$ These actors are part of the broader international legal system.

Information technology has enabled governments at many levels, the private sector, formal and informal groups and networks, and individuals to communicate instantaneously across the world. For example, Tumblr hosted 532 million blogs as of August 2021. Over 409 million people view more than 20 billion pages of WordPress each month; WordPress blogs are written in over 120 languages. Twitter launched a CoviD-19 curated page, which over 160 million people have visited over 2 billion times as of July 2020. ${ }^{7}$ Mobile phones have become ubiquitous with over 5.2 billion "unique mobile subscribers," as of August 2021. ${ }^{8}$ Thus, many actors beyond States have become empowered to take actions dealing with problems that can have global effects. They reflect bottom-up empowerment and affect the development and implementation of international legal instruments. At the same time, information technology has enabled authoritarian top-down control to control the coronavirus and facilitated those political leaders who want to flout practices directed to controlling coronavirus transmission.

Effective collective action requires access to information, and importantly, transparency about the emergence of the virus, its tracks, its effects, and the efforts to control it. Addressing Covid-19 involves international and domestic law, public and private sectors, and civil society. It illustrates once again that the lines between international and domestic and between public and private are blurring and that the gaps between national and international and public and private actions need to be closed.

In a more broadly conceived public international law, legal instruments are more diverse than in the legacy framework. They include not only binding international agreements, customary international law, and general principles of law, but also a second tier of nonbinding legal instruments produced by consensus, and a third tier of individual voluntary commitments. The key characteristic of nonbinding legal instruments is that while States or other actors have agreed to a common text, they are not legally bound to comply with it,

6 Martin Kulldorf, Sunetra Gupta and Jay Bhattacharya 'Great Barrington Declaration' (4 October 2020) <https://gbdeclaration.org > accessed 13 October 2020.

7 Twitter has been deleting or placing warnings on tweets that violate its COVID-19 misleading information policy. As of 12 January 2021, Twitter had removed 8,493 tweets and challenged 11.5 million accounts.

8 'Data' (GSMA Intelligence) <https://www.gsmaintelligence.com/data> accessed 30 August 2021. 
which means they cannot be brought into international or national courts for failure to comply. Practice indicates, though, that in some cases compliance may be as good as for binding international agreements. Voluntary individual commitments differ from the above in that they are not prescribed by a consensus but rather differ from each other. They may be undertaken pursuant to a common goal, as in the Paris Agreement on climate change. Corporations in particular have made such commitments for a range of environmental goals.

In controlling COVID-19, we need a mix of these forms of legal instruments and of other instruments affecting behaviour that do not rise to the level of a formal legal instrument. Controlling the COVID-19 pandemic means that formal and informal legal instruments, codes of conduct, and suites of best practices need to exist at many different levels, including the very local. They need to encompass many actors other than States and the WHO. To address Covid19, all States, private actors, and civil society need to know about relevant laws, codes of conduct, best practices, and other instruments such as declarations for quarantines, wearing of masks, social distancing, etc. Sharing experience with implementing them and with their effects is important.

Nongovernmental institutions have a potentially important role to play. They can be a significant source of relevant laws and good practices and identify gaps and weaknesses in domestic policies and laws. The December 2019 International Conference of the Red Cross and Red Crescent, for example, adopted a new non-binding guidance document regarding legal frameworks for preparing for and responding to disasters. ${ }^{9}$ The Conference and related resolutions drew attention to important equity issues such as the protection of vulnerable groups. Such documents help both the Red Cross and the Red Crescent, and other groups, to provide domestic assistance in disasters, including pandemics. They form part of the relevant frameworks.

The new CoviD-19 Law Lab, formalized in July 2020, is an important step in bringing together the relevant laws, regulations, nonbinding legal instruments, good practices, policies and other relevant commitments by States and other actors. The Law Lab is a joint project of the United Nations Development Programme (UNDP), the World Health Organization, the Joint United Nations Programme on HIV/AIDS and the O'Neill Institute for National and Global

9 The Conference adopted Resolutions entitled "Disaster Laws and Policies that Leave No one Behind" and "Time to Act: Tackling Epidemics and Pandemics Together": see Rachel Macleod, 'Tackling Disasters and Pandemics Together with Laws and Policies that Leave No One Behind' (2020) 24(21) ASIL Insights <https://www.asil.org/insights/volume/24/issue/ 21/tackling-disasters-and-pandemics-together-laws-and-policies-leave-no-one > accessed 13 October 2020 . 
Health Law at Georgetown University. The database of legal instruments covers declarations of a state of emergency, quarantine measures, disease surveillance, mask-wearing, social distancing, and access to medication and vaccines.

The Covid-19 crisis illustrates the need for breaking down the walls between public national and international law and between public and private. It demonstrates that we need to aggregate and consider a variety of legal instruments and commitments. It supports reconceptualizing international law around the notion of "public" and integrating international and domestic, public and private law into a framework for considering, undertaking, and evaluating actions.

\section{$4 \quad$ Recognizing and Maintaining Norms}

In the kaleidoscopic world, States and other actors need to be guided by shared norms that reflect commonly held values embedded in diverse cultures. We assume an essentially social contract in which norms arise or are recognized from an interactive process. They serve as prescriptive obligations that actors generally accept. Such norms unify disparate elements and can provide stability in our emerging chaotic international system. In the context of the covid19 pandemic, shared norms foster collaboration for the public good, both globally and locally, to control the virus.

We can identify norms that are fundamental to a just, peaceful, and robust international system and central to generating and maintaining public goods: in this case, the control of the coronavirus. These include cooperation, avoiding harm, human dignity and equity, transparency, and accountability. ${ }^{10}$

Cooperation is a fundamental norm in international law. It is found in diverse cultures and has deep biological roots in the behaviour of animals. The norm of cooperation is embedded in international agreements and other legal instruments and in many private sector instruments. Cooperation enables people to achieve benefits that they could not achieve on their own or to prevent problems or situations from spiralling downward, often drastically so, and causing everyone to suffer. When we are locked into the same space for the foreseeable future, as we are with pandemics and other crises, the shadow of the future can lead to cooperation.

We can distinguish two different forms of cooperation: joint efforts, which we may refer to as collaboration, and coordination of a myriad of separate

10 Brown Weiss ( $\left.\mathrm{n}_{5}\right)$. 
efforts. Scientists working on the coronavirus are often engaged in joint efforts. Coordination may be needed to ensure that international, national, and local measures to limit the virus are effective.

Many international agreements embody the norm of avoiding harm. It is linked to the norm of cooperation, because cooperation may be essential to avoiding harm. In the context of the COVID-19 pandemic, avoiding harm means controlling transmission, avoiding deaths, and providing a healthcare system that minimizes suffering. I would argue that it also implies respect for scientific evidence and an obligation not to make false statements and engage in behaviour that impedes measures needed to control the virus.

The norm of human dignity and equity is complicated in the context of a pandemic. The effects of CoviD-19 fall disproportionately on low-income countries and on marginalized and vulnerable groups. Many States do not have adequate health care systems so that many people do not have access to routine health care or they do not have adequate resources to deal with a pandemic. This makes it much harder to identify, monitor, track contacts, and treat disease, which affects the human dignity to which all people are entitled.

The norm of transparency holds that information must be made available. In the context of COVID-19 and similar health crises, it means that a State must make information available as soon as the presence of the disease is known and continue to make information available about its transmission, effects, and treatment.

The norm of accountability calls for mutual accountability between all participants in the system. It provides the glue for the other norms. States are accountable to each other, but private companies, civil society organizations, communities, and even individuals must be accountable. In the kaleidoscopic world, accountability is especially difficult. In the context of the CoviD-19 pandemic, leaders should be accountable when by their actions, thousands of people needlessly die, marginal and vulnerable groups suffer enormous hardship, and human rights are violated under cover of the pandemic.

In the context of the pandemic, we might also identify a norm related to scientific knowledge. Understanding the virus, its spread, its effect, and its treatment is critical. In the international legal order, we often view scientific knowledge as more or less static for a significant period of time in that our understandings exist for at least months, or even years. But the scientific knowledge about CoviD-19 is dynamic and rapidly changes, which has implications for international law. Advances in scientific knowledge come from widespread participation in the scientific endeavours and from transparency in sharing the resulting knowledge. States need to facilitate this and not stand in the way of cooperation and transparency. 
One can argue that we have a moral obligation to seek scientific knowledge so as to understand the virus, cure or prevent the disease, control its spread, and lessen its harmful, often devastating effects. ${ }^{11}$ This carries both positive and negative obligations. On the positive side, it is an obligation to engage in scientific research and technological development, to monitor developments, and to disseminate data and information. On the negative side, it is an obligation not to impede research, monitoring, testing, and access to data. It is also an obligation not to falsify data or manipulate it for political purposes, and not to deliberately disseminate false information. While this moral obligation applies more broadly to other problems, it is particularly acute for pandemics and similar problems where scientific knowledge is especially dynamic. One could treat this as a norm regarding the dynamic process of generating and using scientific knowledge.

The norms outlined here are fundamental for a kaleidoscopic world in addressing pandemics. With the many different actors and varied legal and other instruments, they provide a means for bringing cohesion to producing and maintaining a public good, in this case controlling CoviD-19.

International law has addressed issues of providing a public good, as for example in controlling the depletion of the ozone layer. The covid-19 pandemic poses the ultimate public goods problem in the context of a kaleidoscopic world. Control of the disease is at the same time an individual good, a community good, and a global public good. The virus knows no boundaries. In this sense it is similar to but more dangerous than other viruses that have threatened us in that it is more contagious than Ebola and more lethal than recent flu viruses.

A public good has two characteristics. It is non-exclusive in that others cannot be excluded from sharing in it, and it is non-rivalrous in that one person's consumption of the public good does not reduce the quantity available to others. Global public goods are those whose benefits are spread widely across space and time. Measures, including legal instruments, are needed to produce global public goods and to maintain them.

Global public goods are like other public goods, except that their effects are not confined within national borders but rather cross them. They may exist for

11 See Charles Weiss, The Survival Nexus: Science, Technology and World Affairs (OuP 2022). 
a significant period of time. Global public goods are usually not pure public goods but rather have a significant private element. This configuration may change over time.

For the COVID-19 pandemic, the global public good is control of the disease. The measures for producing this global public good are critical and have major implications for our success in doing so and for international law. We can distinguish three different kinds of measures: ${ }^{12}$ additive measures in which the public good is sum of contributions from different actors; best-shot measures in which the public good is determined by the technology producing the best outcome; and weakest-link measures in which the public good is only as effective as the weakest link in the chain. All three are relevant to the public good of controlling the pandemic.

At present, controlling the CoviD-19 pandemic exemplifies the first category of measures in that it depends upon the sum of what States and many other actors are doing to control it and to prevent its spread. Here the record is spotty at best. The virus as of this writing is not under control. Some States have refused to develop a national strategy for dealing with the pandemic. Some States lack the capacity to do so. Only a very few, such as New Zealand, an island State, have been successful in controlling the virus within the State's borders.

States are individually exercising national sovereignty in an effort to stop virus transmission. They have closed their borders, and locked down cities, regions, or communities within their borders. They have imposed varying travel restrictions. Their efforts are ad hoc, reflecting in part changes in the status of the virus within their countries, and in part efforts to go it alone in addressing the pandemic. States are generally not coordinating with each other in their efforts.

Producing a public good generally requires cooperation and coordination of actions. ${ }^{13}$ States and all the many other relevant actors are obligated to take certain measures or engage in certain behaviours and to refrain from certain behaviours or actions. In the context of the Covid-19 pandemic, this means that States, the private sector and civil society are obligated to take measures

12 William Nordhaus, 'Paul Samuelson and Global Public Goods' in Michael Szenberg, Lall Ramrattan, andAronGottesman(eds),SamuelsonianEconomicsandtheTwenty-FirstCentury (Oxford Scholarship Online 2009) <https://oxford.universitypressscholarship.com/view/ 10.1093/acprof:oso/9780199298839.0o1.00o1/acprof-978o199298839-chapter-6> accessed 13 October 2020.

13 See Inge Kaul, Isabelle Grunberg, and Marc Stern, Global Public Goods: International Cooperation in the $27^{\text {st }}$ Century (OUP 1999). 
to conduct tests, monitor transmissions, provide access to data, and engage in certain practices to minimize transmission. While these measures need not be uniform, they do need to be taken pursuant to a common goal of pursuing the public good. Scientists need to participate in research and monitoring and the results need to be publicly shared.

Our treatment of drugs in international law provides a relevant example. To combat illegal drugs, States agreed to take certain actions within their countries and to co-ordinate with other States in doing so. The United Nations General Assembly report from its UNGA sponsored conference on drugs in 2016 articulated a doctrine of common and shared responsibility for this scenario. The doctrine is especially relevant for the COVID-19 pandemic, in which States and other actors need to co-ordinate their strategies and measures for effective collective action. Common and shared responsibility extends not only to States and international organizations but also to subnational institutions and to community level actions.

The public good of controlling the coronavirus also depends upon finding a safe and effective vaccine or vaccines and making these available worldwide. This is referred to as finding "the best shot technology." A handful of countries and many private companies are racing to do this. The problem is fraught with dangers. The medical scientific community has standards for determining when a vaccine is effective and safe to distribute broadly, but States may not necessarily accept these judgments and may try to suppress or alter these judgments for political reasons.

Widespread distribution of the vaccine or vaccines will be critical to controlling the coronavirus, but international consensus on how this will be done is still lacking. The World Health Organization established the CoviD-19 Vaccine Global Access Facility for States to cooperate in developing a vaccine and to agree on its distribution. As of May 2021, the Russian Federation, the United States and certain other countries had not yet signed the commitment agreement. ${ }^{14}$ The new covax Facility, co-led by who, is intended to assist lowincome countries access the vaccines. Access to the vaccine raises profound ethical issues among countries and within them. Moreover, the anti-vaccine movement in the United States, which has been spreading through social media to other countries, could complicate efforts to achieve herd immunity when vaccines become available.

14 US President Biden has reversed the US position against working with the WHO and in February 2021 committed an initial $\$ 2$ billion to the covid-19Vaccines Advance Market Commitment (COVAX AMC), and \$2 billion more through 2021 and 2022. 
The global public good of controlling the coronavirus especially depends upon the third category of measures: overcoming the weakest link in the chain. Otherwise the weakest link can defeat the effort. As long as there is no global community (herd) immunity and no effective vaccine globally available, we face the nasty possibility that the coronavirus can slip undetected into areas that have been free of it. While we have considerable experience in dealing with the weakest link problem in our efforts to control the depletion of the ozone layer, among other environmental problems, we face a greater challenge in doing so in a pandemic in which all of us are relevant actors. Our experience with limiting Ebola and SARs is relevant, but they were contained before they spread globally.

The Covid-19 crisis reveals the need to reconceptualize public international law to broaden its scope, to be more inclusive with regard to relevant actors beyond States, and to encompass other forms of legal instruments and commitments other than binding agreements. The refusal or hesitancy of certain States to collaborate only accelerates the need to recognize our shared values and to engage all actors in pursuing them to prevent and control the pandemic, a global and local public good, and to enlist private goods for the public interest.

Dealing with COVID-19 in a kaleidoscopic world is difficult. Just as governments and diverse groups can press for addressing social justice issues in the context of the pandemic, other groups can work transnationally to ignore these issues. In the kaleidoscopic world, it has become easier to undermine respect for the rule of law and to promote the flouting of it. Groups and even individuals can work transnationally to undermine trust in scientific opinion and effective responses in controlling the pandemic. To counter these dangers and avoid chaos, shared norms among governments and the multiple actors are essential. While legal instruments and actions will differ, the many actors must work toward the common public good. In the end, this is the potential force of international law. 